\title{
Development of Salt Hydrolysis Module Based on guided Inquiry to Increase The Critical Thinking Ablility of 11th Grade High School Students
}

\author{
Annisatul Qaidah ${ }^{1}$, Hardeli $^{2}$ \\ Magister of Chemical Education FMIPA Padang State University
}

\begin{abstract}
This study aims to produce a guided inquirybased salt hydrolysis module to improve students' critical thinking skills by determining the level of validity, practicality and effectiveness of the module. The type of research used is research development or Research and Development (R\&D). The sampling technique uses cluster purposive sampling. The number of samples is 57 students from both schools. The development model used is the Plomp development model which has three stages namely the initial investigation phase (preliminary research phase), the prototype phase (prototyping phase) and the assessment phase (assessment phase). The research instruments used were interview sheets, questionnaires in the form of validation and practicality sheets, objective questions, and critical thinking questions. Data analysis techniques using SPSS 16 software. The results obtained by N-gain experimental class is higher than the control class that is experimental class 1 and 2 have $\mathrm{N}$-gain 64.65 and 59.46, while control classes 1 and 2 have $\mathrm{N}$-gain 60,83 and 58.6 with significant differences. Hypothesis test results show a significant difference between the critical thinking skills of the experimental class and the control class, both in schools with high and low student abilities.
\end{abstract}

Keywords:- modules, salt hydrolysis, guided inquiry, Critical thinking, Plomp Development .

\section{INTRODUCTION}

Salt hydrolysis material is included in the chemistry subjects of class XI SMA listed in the syllabus with Basic Competence 3.11 which analyzes the ion balance in the salt solution and determines its $\mathrm{pH}$, and Basic Competence 4.11 which reports an experiment to show the acidic nature of various salt solutions. This material discusses the reaction of cations or anions from a salt with water. This reaction is abstract and certainly cannot be seen by students. Students can only observe symptoms or facts in the form of $\mathrm{pH}$ values carried out through experiments.

Based on the results of interviews with several chemistry teachers, the results of the questionnaire given to students found several problems. The use of modules is still rarely applied to the learning process. Students in the School only have teaching materials such as textbooks provided in the library, so there is no variation in using teaching materials that aim to increase understanding of chemistry in particular. Solutions to make students become active in the learning process include implementing an active learning model or by designing a set of teaching materials, one of which is in the form of modules. Modules can be used as teaching materials that help teachers in the learning process.

The selection of teaching materials with the right learning model or method can support the success of the learning process (Isworini, 2015: 9). There are three reasons for the need to develop teaching materials, namely the availability of teaching materials that are in accordance with the demands of the curriculum, the characteristics of the targets and the demands of learning problems (Depdiknas, 2008: 8), one of the teaching materials that can be developed is a module.

The module is a book that is written so that students can learn independently with or without guidance from the teacher (Ministry of National Education, 2008: 13).

One active learning model is the guided inquiry learning model. The goal in guided inquiry according to Stobaugh (2013: 5) is that teachers should give opportunities to students to become a problem solver, a scientist, or mathematician.

Guided inquiry can be interpreted as a learning model that can develop learning methods of active students by discovering themselves, investigating themselves, then the results obtained will last long in memory, not easily forgotten by students (Hosnan, 2014: 282). Various ways have been applied by teachers to improve students' thinking and active abilities.

Ennis (2007: 26) critical thinking skills are higher order thinking abilities that have the potential to increase students' critical analysis power in line with intellectual abilities.

\section{RESEARCH METHOD}

This type of research used in this study is research and development or Research and Development (R \& D). The test subjects in the development of the guided inquirybased salt hydraulic module were to improve the critical thinking skills of students of class XI at SMAN 1 Solok Selatan and SMAN 4 Solok Selatan. The determination of the trial school is done by grouping schools based on the average national exam scores of students in chemistry subjects in 2018. The development model used in this study uses the Plomp design model (Plomp and Nieveen, 2013: 
30). The Plomp model consists of three stages of development, namely preliminary research, prototyping phase, assessment phase.

This type of data is primary data because the data is obtained directly through the provision of validity test questionnaires, practicality tests and effectiveness tests on research subjects.

Product trials are conducted to obtain practicality and effectiveness data used to revise the product. The product trial consists of three stages: individual evaluation is carried out to produce prototype III, small group evaluation to produce prototype IV and field trials.

Techniques used to analyze items about learning outcomes include validity, the degree of difficulty of the questions, distinguishing features, reliability.

\section{Validity}

The validity of an item from a learning achievement test is the accuracy of the measurement possessed by a learning achievement test item in measuring what should be measured through the item item. The validation of the learning achievement test items is calculated using the biseral point correlation as follows (Arikunto, 2015: 93).

$\mathrm{r}_{\mathrm{pbi}}=\frac{\mathrm{Mp}-\mathrm{Mt}}{\mathrm{SDt}} \frac{\sqrt{\mathrm{p}}}{\mathrm{q}}$

Information:

Rpbi = coefficient biseral correlation, which in this case is considered as the coefficient of item validity.

$\mathrm{Mp}=$ average score of students who answered correctly the item sought for validity.

$\mathrm{Mt}=$ average score of total score

$\mathrm{SDt}=$ standard deviation of the total score

$\mathrm{P}=$ proportion of students who answered right

$\mathrm{q}=$ proportion of students who answer incorrectly

\section{Degree of Trouble Difficulties}

The degree of difficulty of the problem is a number that indicates the difficulty and ease of a problem. A good question is a problem that is not too difficult and not too easy, in other words the degree of difficulty the problem is being (Latisma, 2011: 155). The formula used to determine the level of difficulty of the problem is as follows.

$\mathrm{B}=\frac{\mathrm{B}}{\mathrm{J} s}$

Information:

$\mathrm{P}=$ difficulty index

$\mathrm{B}=$ many students answer the questions correctly

JS $=$ number of students who took the test

\section{Distinguishing Power}

Distinguishing power is the ability of an item to distinguish between high-ability and low-ability test takers. Distinguishing power of a problem can be calculated using the following formula (Latisma, 2011: 161).
$\mathrm{D}=\mathrm{P}_{\mathrm{A}}-\mathrm{P}_{\mathrm{B}}$ dengan $\mathrm{P}_{\mathrm{A}}=\frac{\mathrm{B}_{\mathrm{A}}}{\mathrm{J}_{\mathrm{A}}}$ dan $\mathrm{P}_{\mathrm{B}}=\frac{\mathrm{B}_{\mathrm{B}}}{\mathrm{J}_{\mathrm{B}}}$

Information:

$\mathrm{D}=$ Power of distinguishing problems

$\mathrm{PA}=$ Proportion of tastes under the group that can correctly answer the item in question.

$\mathrm{PB}=$ Proportion of top group tastes that can correctly answer the item in question.

BA $=$ Number of top group tastee who can answer correctly the item in question.

$\mathrm{BB}=$ Number of tastes under the group that can answer correctly the items in question.

$\mathrm{JA}=$ Number of tastees included in the upper group

$\mathrm{JB}=$ Number of tastees included in the lower group

\section{$>$ Reliability}

Test reliability is the ability of the test to give the same results (fixed) if given to homogeneous subjects. Determination of the reliability of test results using the Kuder-Richardson formula 21 (Sudijono, 2009: 253).

$$
\begin{aligned}
& r_{11}=\left(\frac{k}{k-1}\right)\left(1-\frac{M t(k-M t)}{k S t^{2}}\right) \\
& M_{t}=\frac{\sum X_{t}}{N} \\
& S_{t}^{2}=\frac{\sum X_{t}^{2}-\left(\frac{\left(\sum X_{t}\right)^{2}}{N}\right)}{N}
\end{aligned}
$$

Information:

r11 $=$ Test reliability coefficient

$\mathrm{k}=$ Many items

$\mathrm{Mt}=$ Mean total

St $2=$ Total variance

$\mathrm{N}=$ Many students

$\sum \mathrm{x}=$ Total number of scores

Techniques used to analyze data include: validity analysis techniques, practicality analysis techniques and effectiveness analysis techniques.

\section{Validity Analysis Techniques}

The validator's evaluation of each statement was analyzed using Kappa Cohen or called kappa with the final result of processing obtained kappa moment.

Moment kappa $(\mathrm{k})==\frac{P-P e}{1-P e}$

Information:

$\mathrm{K}$ = kappa moment indicating product validity

$\mathrm{P}=$ Realized proportion, calculated by the number of values given by the validator divided by the maximum number of values

$\mathrm{Pe}=$ Unrealized proportion, calculated by means of the sum of the maximum values reduced by the total number of values given by the validator divided by the sum of the maximum values 


\section{Practicality Analysis Techniques.}

The practicality sheet assessment was obtained from administering teacher response questionnaires and student response questionnaires which were also analyzed using Cohen's Kappa.

\section{Effectiveness Analysis Techniques}

- Analysis of Student Learning Outcomes Tests

Analysis of effectiveness data was obtained from student learning outcomes assessment sheets using the final learning test. The effectiveness of the module on student learning outcomes can be known through hypothesis testing, before testing the hypothesis, a basic assumption test is conducted which is the normality test and homogeneity test with the help of SPSS software.

Normality test is performed to determine the distribution of the two data groups (normal or not). The normality test used is Kolmogorov-Smirnov. The static hypothesis for the normality test is:

$\mathrm{H}_{0}$ : Data is normally distributed

$\mathrm{H}_{1}$ : Data is not normally distributed

Decision making criteria are based on the significance value (probability). $\mathrm{H}_{0}$ is accepted if the significance value> 0.05 , and rejects $\mathrm{H}_{0}$ if vice versa.

Homogeneity variance test aims to see whether the two data groups have homogeneous variance or not.

The criteria for accepting $\mathrm{H}_{0}$ are based on the significance value in the test table of homogeneity of variance. If the significance value is $>0.05$, accept $\mathrm{H}_{0}$ and reject $\mathrm{H}_{0}$ if vice versa.

If the data is normally distributed and homogeneous, the hypothesis is tested using the $t$ test. The significance value taken is the value for equal variances assumed. If the data is normally distributed but not homogeneous, then hypothesis testing is also done by test, but what is seen is the significance value for equal variances not assumed. Statistical hypothesis for the $t$ test:

$\begin{array}{ll}\mathrm{H}_{0} & : \mu 1=\mu 2 \\ \mathrm{H}_{1} & : \mu 1>\mu 2\end{array}$

The criterion for acceptance of $\mathrm{H}_{0}$ is accepting $\mathrm{H}_{0}$ if the value of significance> 0.05 , and rejecting $\mathrm{H}_{0}$ if vice versa.

If the data are not normally distributed, then the hypothesis is tested using the Mann-Whitney Test (U Test). The statistical hypothesis and acceptance criteria of the $\mathrm{U}$ Test are the same as the $t$ test, but the $U$ Test does not need to meet normal and homogeneous assumptions.

- Analysis of Student Learning Outcomes Tests

Analysis of student activity can be searched using the percentage approach with the following equation (Kunandar, 2007: 97)

$\% \mathrm{~A}=\frac{\mathrm{F}}{\mathrm{X}} \times 100 \%$

Information:

$\% \mathrm{~A}=$ Percentage of student activities

$\mathrm{F}=$ Number of student activity scores

$\mathrm{X}=$ Maximum number of scores.

\begin{tabular}{|c|c|c|}
\hline $\begin{array}{c}\text { \% Activity } \\
\text { Student }\end{array}$ & Category & After Conversion Category \\
\hline $81 \%-100 \%$ & Very high & Very effective \\
\hline $61 \%-80 \%$ & High & Effective \\
\hline $41 \%-60 \%$ & Medium & More effective \\
\hline $21 \%-40 \%$ & Low & Low effective \\
\hline $0 \%-20 \%$ & Very low & Not effective \\
\hline
\end{tabular}

(Ridwan, $2009: 89$ )

Table 1:- Student Activity Criteria

- Analysis of Critical Thinking Abilities

Analysis of critical thinking skills is done by giving a score on the answers given. Scoring is done by referring to the assessment rubric which is modified from the following Finken and Ennis (Zubaidah, 2015: 211).

\begin{tabular}{|c|ll|}
\hline Score & & \multicolumn{1}{c|}{ Descriptors } \\
\hline 5 & $\bullet$ & All concepts are true and specific \\
& $\bullet$ & All answers are correct, clear and specific, supported by strong, true, clear arguments \\
& - & Flow of good thinking, all concepts are interrelated and integrated \\
& - & Grammar is good and correct \\
& - & All aspects appear, evidence is good and balanced \\
& - & Most concepts are true, clear, but lacking specifics \\
& - & Gost of the answers are correct, clear, but not specific enough \\
& - & Good thinking flow, most concepts are interrelated and integrated \\
& & All aspects appear, but not yet balanced \\
\end{tabular}




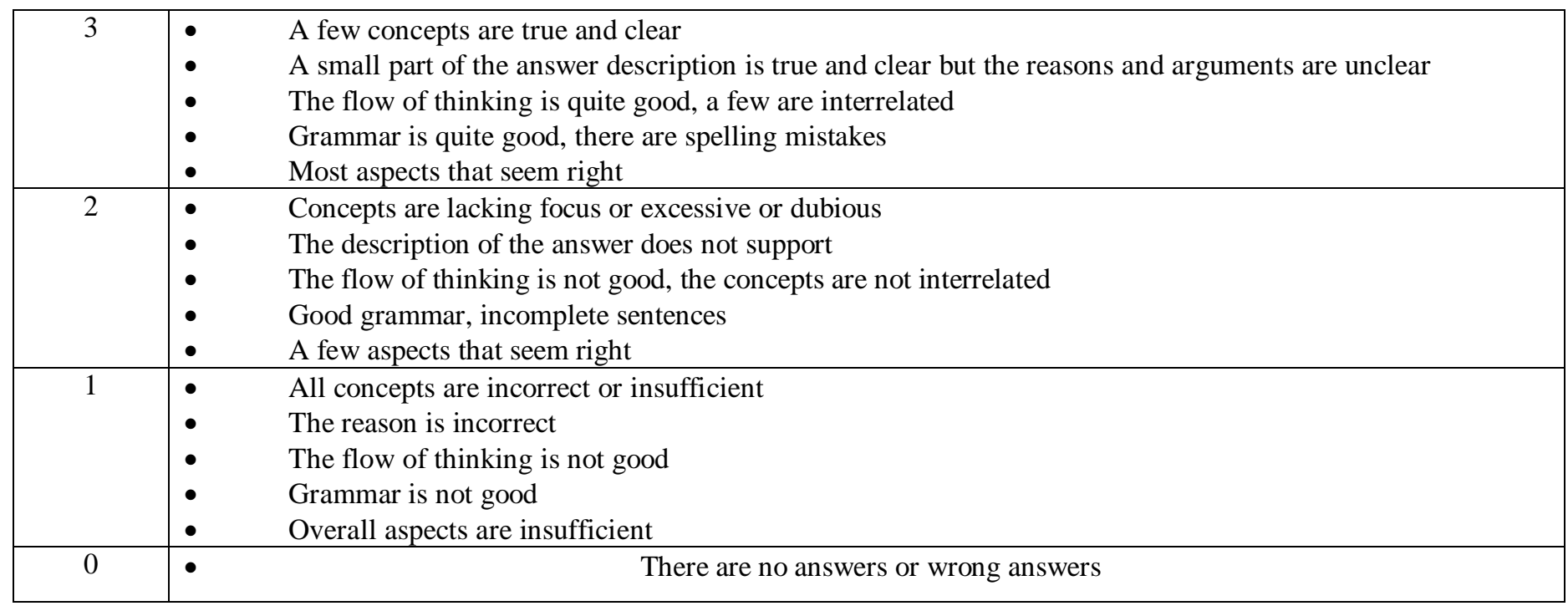

Table 2:- Modified Critical Thinking Rubric of Finken and Ennis

Then the score is converted to a percentage with the criteria in Table 3.

\begin{tabular}{|c|c|}
\hline Skor(\%) & Kriteria \\
\hline $81-100$ & Sangat baik \\
\hline $61-80$ & Baik \\
\hline $41-60$ & Cukup \\
\hline $21-40$ & Surang \\
\hline $0-20$ & Sangat kurang \\
\hline
\end{tabular}

(Arikunto, 2009: 44)

Table 3:- Criteria for Student Ability Levels

Data analysis of critical thinking skills of the experimental class and the control class were also tested by the hypothesis.

\section{RESULTS}

The product developed in this study is a guided inquiry-based salt hydrolysis module to improve the critical thinking skills of students in class XI SMA / MA. This research was conducted based on the stages of the Plomp development model. The results of the research carried out are described as follows.

\section{Preliminary Research}

This stage, identification or analysis is needed to develop a guided inquiry-based salt hydrolysis module. The analysis results that have been obtained can be described as follows.

\section{- Need analysis}

Based on the results of interviews with chemistry teachers, it is known that the chemistry learning methods applied in schools have varied, such as lecture, discussion, and practicum (experimental) methods. In practice the lecture method still dominates, due to the lack of active students in the learning process to construct their own concepts.

\section{- Student Analysis}

Based on the results of student interviews, information was obtained that some students still had difficulty understanding salt hydrolysis material. Difficulties include making the reaction of salts undergoing hydrolysis, thus causing doubt to determine the nature of the salt. This is justified by some teachers who say that salt hydrolysis material is difficult material for students and also students still find it difficult to distinguish the formula for determining the $\mathrm{pH}$ of hydrolysis and buffer.

\section{- Curriculum Analysis}

Curriculum analysis aims to find out what abilities students must obtain.

\section{- Concept Analysis}

Concept analysis aims to identify the main concepts taught, elaborate and arrange them systematically to achieve indicators of competency achievement.

\section{Prototyping Phase}

The prototyping phase produces 4 types of prototypes as follows. 


\section{- Designing Modules}

Modules that are designed have components that are useful to facilitate students in the learning process. The components contained in the module are adjusted to the module components according to the Directorate of Education (2008)

\section{- Self Evaluation}

This stage focuses on errors that appear like mistakes in punctuation, typing letters and aspects of the completeness of module components that are designed with guided inquiry stages to improve critical thinking skills.

\section{- Expert Review}

Sugiyono (2012: 352) which states that to test the validity, judgment experts can be used with a minimum of three people, but previously the data collection instruments used must also be validated in advance by the validator.

Based on the analysis results, the average module validation as a whole is 0.88 with a very high category. These results indicate that the guided inquiry-based salt hydrolysis module is valid. The results of this prototype revision are called prototype II. The following are the results of the assessment of each aspect provided by the validator.

\begin{tabular}{|c|c|c|c|}
\hline No & Rated aspect & Component & Criteria \\
\hline 1 & Content & 0,88 & Very high \\
\hline 2 & Construct & 0,89 & Very high \\
\hline 3 & Language & 0,84 & Very high \\
\hline 4 & Graphic & 0,92 & Very high \\
\hline \multicolumn{2}{|l|}{ Average } & 0,88 & Very high \\
\hline
\end{tabular}

Table 4:- Module Validation Results

\section{- Individual Evaluation (One-to-one Evaluation)}

Individual evaluation (One-to-one Evaluation) was carried out through interviews with three students of class XI MIA 2 SMAN 1 Solok Selatan with low, medium and high abilities.

\section{- Prototype IV}

Test the practicality of the module developed in prototype III by conducting a small group evaluation. The evaluation of this small group was done by teaching salt hydrolysis material to nine students of SMAN 1 Solok Selatan with high, medium and low abilities. Learning is carried out twice by giving each student module design.

The results of the student practicality questionnaire showed that aspects of ease of use, benefits and attractiveness of teaching materials have a very high level of practicality. Overall results of practicality questionnaire students obtained an average kappa moment of 0.82 with a very high level of practicality module. The results of the small group evaluation are prototype IV, which is tested on large groups

\section{Assesment Phase}

The assessment phase (Assessment Phase) is carried out to determine the practicality and effectiveness of the guided inquiry-based module that has been developed. This assessment phase was tested on a large group in two high schools namely SMA N 1 Solok Selatan and SMA N 4 Solok Selatan. The module practicality data is seen and determined from the analysis provided by students and teachers who have carried out the learning process with the module

- Practicality results from student response questionnaires

Questionnaire practicality of student responses filled by 57 students after learning to use modules. Guided inquiry-based salt hydrolysis modules that have been filled out by students are analyzed for answers. This analysis is done by analyzing each student's answer in answering the questions contained in the module, so based on this analysis can prove that the module has a very high practicality.

\begin{tabular}{|c|c|c|c|}
\hline No & Assessment Aspects & School 1 & School 2 \\
\hline 1 & Orientation & 92 & 86 \\
\hline 2 & Exploration and Concept Formation & 87 & 84 \\
\hline 3 & Aplikasi & 94 & 91 \\
\hline 4 & Penutup & 94 & 86 \\
\hline \multicolumn{2}{|c|}{ Rata - rata } & 92 & 85 \\
\hline
\end{tabular}

Table 5:- Data Analysis of Student Answers in Modules

\section{- Practicality results from student response questionnaires}

The practicality questionnaire of the teacher's response was filled by three chemistry teachers after learning to use the module. The average acquisition of kappa moments for practicality is 0.79 with a high level of practicality. The results of the practicality data analysis showed that the guided inquiry-based salt hydrolysis module that was developed was practically used in the learning process. 
- Effectiveness Test (Learning Outcomes and Activities)

\section{$\checkmark$ Learning Outcomes}

The results of data analysis of the two schools show that the experimental and control classes are normally distributed and homogeneous, where significant values $>0.05$ then $\mathrm{H}_{0}$ is accepted and otherwise.

\begin{tabular}{|c|c|c|c|c|}
\hline Kelas & N & Gain score & Asym.s ig & Keputusan \\
\hline Eksperimen SMAN 1 & 29 & 64,65 & & Tolak $\mathrm{H}_{0}$ \\
\hline Kontrol SMAN 1 & 32 & 60,83 & 0,491 & Terima $\mathrm{H}_{0}$ \\
\hline Eksperimen SMAN 4 & 28 & 59,46 & \\
\hline
\end{tabular}

Table 6:- Hypothesis Testing Student Learning Outcomes

In Table $6 \mathrm{H}_{0}$ is rejected, it means that the learning outcomes of students with high ability of students who learn using modules and without modules differ significantly. The average learning outcomes of students who use modules in high school are higher than the average learning outcomes of students who do not use modules.

\section{$\checkmark$ Critical Thinking Ability}

The use of modules has an effect on the ability to think critically done hypothesis testing.

\begin{tabular}{|c|c|c|c|c|c|}
\hline Kelas & $\mathbf{N}$ & & Std. Dev & Asym.s ig & Keputusan \\
\hline Eksperimen SMAN 1 & 29 & 75,6 & 11,16 & \multirow[t]{2}{*}{0,003} & \multirow[t]{2}{*}{ Tolak $\mathrm{H}_{0}$} \\
\hline Kontrol SMAN 1 & 32 & 62,5 & 18,53 & & \\
\hline Eksperimen SMAN 4 & 28 & 62,32 & 10,88 & \multirow[t]{2}{*}{0,001} & \multirow[t]{2}{*}{ Tolak $\mathrm{H}_{0}$} \\
\hline Kontrol SMAN 4 & 30 & 49,75 & 15,42 & & \\
\hline
\end{tabular}

Table 7:- Results of the Experimental and Control Critical Thinking Hypothesis Tests.

Decision to reject Ho means the critical thinking ability of students who learn by using modules and without using modules differ significantly. The average critical thinking ability of students who use modules is higher than students who do not use modules.

\section{DISCUSSION}

The module teaching materials developed are said to be of high quality if they have valid, practical and effective criteria. The module valiadation results from the content component, construction component, linguistic component and graphic component have an average of 0.88 with a very high validity category, so that the hydrolysis module is valid in the learning process.

Practicality testing by students is carried out at the small group stage, and field tests. The results of the assessment of the practicality of small groups and field tests obtained an average kappa moment of 0.82 and 0.82 with a very high validity category.

The results of the practicality assessment by the teacher obtained an average kappa moment of 0.79 with a high category. This shows that the module can increase student interest in learning, the module can support the teacher's role as a facilitator, and the module can help students in independent learning.
The results of practicality assessment by students showed the average kappa moment overall of 0.82 and 0.79 respectively with a very high and high practicality category. This shows that the module designed is already practical.

Hypothesis test results indicate that schools with high student ability influence the use of guided inquiry-based modules on learning outcomes, as well as schools with student ability while there is an influence of the use of modules on learning outcomes.

The use of modules in schools affects the ability of moderate students. and increasing learning outcomes in schools with high student abilities also have an effect. However, student learning outcomes based on the experimental class posttest scores in schools with moderate students' abilities as much as $78.6 \%$ have grades above the $\mathrm{KKM}$ and in schools with high student abilities as much as $81 \%$ have grades above the KKM. Improved student learning outcomes that are being caused by students are less familiar with the learning process that emphasizes students finding their own concepts, because students more easily understand learning if the concept is directly given by the teacher.

The interaction of module use with school-level learning outcomes is determined by the two-way ANOVA SPSS test (Two Way Anova). The results show there is no interaction between the use of modules with the school level on student learning outcomes. The effect of guided 
inquiry-based modules on student learning outcomes will be different at each school level. In schools with high student ability, there are significant differences in learning outcomes between students who study with modules compared with students who do not study with modules, as well as schools with moderate students' abilities.

The results of the analysis of students' critical thinking skills show that the experimental class has the ability to think critically better than the critical thinking skills of the control class both in schools with high student abilities or schools with moderate student abilities, respectively $74.48 \%$ with and $62.33 \%$ with good categories.

Based on the analysis of students 'critical thinking abilities, there are very low indicators of students' critical thinking abilities, namely making and determining the results of consideration based on the background of the facts in question number five with the highest average percentage value of $37.51 \%$ with the less category. This is because students are not careful enough to read the questions given and are weak in analyzing the questions based on the facts given, resulting in students wrong in solving problems. Most students answered that the salt whose cation came from group 1 A would be alkaline was true, and also most students answered with a wrong answer.

The results of hypothesis testing (Table 36) show that the critical thinking skills of students who learn to use the guided inquiry-based salt hydrolysis module differ significantly compared to students who do not use modules, both in high-ability schools or schools with moderate abilities. The high level of students' critical thinking skills in the experimental class compared to the control class in both schools was due to the experimental class's critical thinking skills students were trained through the activities contained in the module.

Knowing whether there is an interaction between the use of modules and the school level of critical thinking skills is determined by the two way ANOVA SPSS test. The significance value obtained $0.921>0.05$, this shows there is no interaction between the use of modules with the school level on critical thinking skills. The influence of guided inquiry-based modules on critical thinking skills will not be different at different school levels.

The results of a simple correlation analysis between critical thinking skills with learning outcomes in schools with high and medium student abilities were obtained respectively 0.368 and 0.395 and sig $<0.05$. These results indicate that there is a correlation between the two variables and the direction (positive), where the higher the ability to think critically, the higher the student learning outcomes.

\section{CONCLUSION}

The research resulted in a product in the form of a guided inquiry-based salt hydrolysis module to improve the critical thinking skills of students in class XI SMA / MA
The guided inquiry-based salt hydrolysis module has a very high level of validity with a kappa moment of 0.88 .

The practicality of the resulting module has a very high level of practicality $(\mathrm{k}=0.82)$ in small group evaluations (small group evaluations) and field tests and (field tests) have a high level of practicality $(\mathrm{k}=79)$ and the results of the teacher's questionnaire responses.

The effectiveness of the module is seen from the comparison of student learning outcomes of the experimental class and the control class Hypothesis test shows that there are significant differences between student learning outcomes in the experimental class and the control class in schools with high student ability, and there is no significant difference between the learning outcomes of the experimental class and control of schools with moderate student abilities.

Hypothesis test results show the resulting module can improve students' critical thinking skills, both schools with high or medium student ability. The experimental class has higher critical thinking skills than the control class.

\section{REFERENCES}

[1]. Arikunto, Suharsimi. 2009. Manajemen Penelitian. Jakarta: Rineka Cipta.

[2]. Direktorat Tenaga Kependidikan. 2008. Penulisan Modul. Jakarta: Departemen Pendidikan Nasional.

[3]. Ennis, Robert H. 2007. "Goals for A Critical Thinking Curriculum"; dalam Costa, Arthur L. 1991. Developing Minds: A Resource Book for Theaching Thinking. Alexandria: Association for Supervision and Curriculum Development.

[4]. Isworini, Sunarno, W., dan Sulistyo, S., 2015. Pengembangan Modul Pembelajaran Hidrolisis Garam Berbasis Model Inkuiri terbimbing Untuk Siswa Madrasah Aliyah Kelas XI, Jurnal Inkuiri, 4(3): 9-20

[5]. Latisma Dj. 2011. Evaluasi Pendidikan. Padang: UNP Press.

[6]. Plomp, Tjeerd dan Nienke Nieveen. 2013. Educational Design Research: An Introduction. Enschede: Netherlands Institute for Curriculum Development (SLO).

[7]. Ridwan. 2009. Belajar Mudah Penelitian Untuk Guru Karyawan dan Peneliti Pemula. Bandung: Alfabeta

[8]. Stobaugh, Rebecca. 2013. Assessing Critical Thinking in Middle and High Schools: Meeting the Common Core. New York: Routledge.

[9]. Sudijono, Anas. 2009. Pengantar Evaluasi Pendidikan. Jakarta: Raja Grafindo Persada.

[10]. Sugiyono. 2012. Metode Penelitian Pendidikan. Bandung: Alfabeta.

[11].Zubaidah, Corebima, Mistianah. 2015. Asesmen Berpikir Kritis Terintegrasi Tes Essay. Symposium on Biology Education: 200-213 